\title{
2. ODP LEG 116 (BENGAL FAN): EXPLANATORY NOTES ${ }^{1}$
}

\author{
Shipboard Scientific Party ${ }^{2}$
}

\section{INTRODUCTION}

Standard procedures for both drilling operations and preliminary shipboard analysis of the recovered material have been regularly amended and upgraded since 1968 during Deep Sea Drilling Project and Ocean Drilling Program drilling. In this chapter, we have assembled information to help the reader understand the basis for our preliminary conclusions and to help the interested investigator select samples for further analysis. This information regards only shipboard operations and analyses described in the site reports in the Initial Reports of the Leg 116 Proceedings of the Ocean Drilling Program. Methods used by various investigators for further shore-based analysis of Leg 116 data will be detailed in the individual scientific contributions published in the Scientific Results part of the volume.

\section{AUTHORSHIP OF SITE REPORTS}

Authorship of the site reports is shared among the entire shipboard scientific party, although the two co-chief scientists and the staff scientist edited the material prepared by other individuals. The site chapters are organized as follows (authorship in alphabetic order in parentheses):

Site Summary (Auroux, Cochran, Stow)

Background and Objectives (Cochran, Stow)

Operations (Cochran, Hanson, Stow)

Lithostratigraphy (Amano, Balson, Brass, Corrigan, Raman, Stow, Tiercelin, Townsend, Wijayananda)

Biostratigraphy (Gartner, Iaccarino, Kacmarska, Proto Decima, Takahashi)

Paleomagnetism (Hall, Sager)

Organic Geochemistry (Ishizuka)

Inorganic Geochemistry (Boulegue)

Physical Properties (Auroux, Kassens, Wetzel)

Wireline Logging (Leger, Williams)

Heat Flow (Cochran)

Seismic Stratigraphy (Cochran)

Summary and Conclusions (Cochran, Stow)

Following the text in each site chapter are summary graphic lithologic and biostratigraphic figures, core descriptions (barrel sheets), and photographs of each core.

\section{SITE APPROACH AND SITE SURVEY}

The survey data used for specific site selections and for correlation between drilling results and seismic reflection profiles are discussed in each site chapter. Geophysical data collected during the site survey and on site approaches are presented in the Site Survey chapter.

\footnotetext{
${ }^{1}$ Cochran, J. R., Stow, D. A. V., et al., 1988. Proc. ODP, Init. Repts., 116: College Station, TX (Ocean Drilling Program).

2 Shipboard Scientific Party is as given in the list of Participants preceding the contents.
}

During transits and site approaches, bathymetric data were collected using 3.5- and $12-\mathrm{kHz}$ Precision Depth Recorders (PDR). The standard 3.5-kHz system uses an array of 12 Raytheon TR-109 transducers and a Raytheon PTR-105B transceiver. The $3.5-\mathrm{kHz}$ profiles were displayed on Raytheon LSR$1807 \mathrm{M}$ flatbed recorder. A Raytheon CESP-III correlator was used to improve signal-to-noise ratio.

The ship has two $12-\mathrm{kHz}$ transducers: a Raytheon TR-12/34 is mounted aft of the moonpool and an EDO 323B is mounted forward, under the bridge. During Leg 116, the EDO was usually employed on site approaches because the aft transducer is in a noisier location. The $12-\mathrm{kHz}$ system uses an EDO $248 \mathrm{C}$ transceiver and a Raytheon flatbed recorder. Water depths reported as uncorrected depths were read from this $12-\mathrm{kHz}$ record, assuming $1500-\mathrm{m} / \mathrm{s}$ sound velocity. Water depths reported as corrected water depths have been further corrected for the velocity of sound in seawater using the tables of Matthews (1939). Depths reported as DPM (drill pipe measure) were based on the - sum of the measured lengths of the drill pipe components that were in the water at the time that the sea floor was detected by the weight-on-bit indicator. Depths reported relative to the rig floor can be converted into depths below sea level by subtracting $11.1 \mathrm{~m}$, the height of the dual elevator stand on the rig floor above sea level during Leg 116.

The sound source for single-channel seismic reflection data consisted of two synchronized 80 -in. ${ }^{3}$ Seismic Systems Inc. water guns. The streamer is a Teledyne 178 with an active section, $100 \mathrm{~m}$ long, towed $500 \mathrm{~m}$ behind the ship. The active section contains 60 equally spaced hydrophones whose output is transformer-coupled to the ship. The signal was amplified and displayed on two analog monitor records at selectable bandwidths in real time; these displays each use an EDO 550 recorder. In addition, the signal was digitized by a Masscomp 561 computer and displayed as a processed record on a Printronix high-resolution graphic printer, approximately $3 \mathrm{~min}$ later. The unprocessed digital signal was also recorded on 9-track magnetic tape using the SEG-Y format and a density of 1600 bits/in.

Magnetic data were collected during the transits between Colombo and the Leg 116 sites using a Geometrics model 801 proton precession magnetometer. Total intensity magnetic field readings were recorded on a strip-chart recorder and written on tape. When we were collecting seismic reflection data, we included magnetic field strength as an entry on the header to each shot. At other times, a digital value was obtained every $99 \mathrm{~s}$.

A variety of navigational aids was used during Leg 116 . The ship has three transit satellite receivers: a Magnavox 1107-GPS, located in the underway geophysics lab, as well as a Magnavox 702A-3 and a Magnavox 4400 GPS, both located on the bridge. The satellite receiver in the underway geophysics lab receives fixes from the Global Positioning System (GPS) as well as the standard transit satellite system. During Leg 116, GPS fixes were received during a roughly 10 -hr time window each day from early afternoon until shortly before midnight local time $($ UTC $+5.5 \mathrm{hr}$ ). The official site positions reported at the beginning of each site chapter are based on an average of GPS and transit satellite fixes received while on station. 


\section{DRILLING CHARACTERISTICS}

\section{Drilling and Coring Techniques}

Three different drilling/coring tools were used during Leg 116. The Advanced Piston Corer (APC) combines the principles of oceanographic piston coring and stored energy in the drill string to produce relatively undisturbed cores at very high recovery rates. It utilizes the technology of the DSDP Hydraulic Piston Corers (Deep Sea Drilling Project, 1983, 1984) while incorporating a simplified seal system that increases the coring force by $76 \%$ (as much as 28,000 pounds). The core bit used for APC coring has a bore large enough to allow the piston corer to be hydraulically extended beyond the bit. In the piston coring operation the corer is locked together by shear pins until it has been lowered into place at the bit by the sand line. Upon landing, the seals of the corer seal off the bore of the drill string. Hydraulic pressure is then applied to the drill pipe with the rig pumps until differential pressure causes the shear pins to fail. The inner core barrel is propelled through the bit while moving past a fixed internal piston. The extended assembly and the core barrel are then recovered with the sand line. Subsequently, the pipe is advanced by the length of the next joint of drill pipe to be added to the drill string.

The Extended Core Barrel (XCB) coring system is a rotary system similar in many ways to the Rotary Core Barrel system (see below). It uses the same core catchers and butyrate core liner. The XCB is a free-fall core barrel that latches in place in the outer core barrel and rotates with the outer barrel. The $\mathrm{XCB}$ can be deployed in the same Bottom Hole Assembly (BHA) as the APC. The XCB core barrel has a cutting shoe rotating with the roller cone bit. This cutting shoe can extend $7 \mathrm{in}$. beyond the face of the roller cone bit and retracts automatically into the core barrel to a position above the roller cones when hard material is drilled. In the extended position the cutting shoe shields the incoming core from disturbance caused by the bit jet hydraulics. The XCB system was used for most of the coring done on Leg 116 because the APC was unable to penetrate the silty turbidites encountered within the upper $20 \mathrm{~m}$ at each site.

The Rotary Core Barrel (RCB) was used for coring in harder formations encountered at Hole 718E. This tool is a modified Hycalog wireline core barrel. This design uses a drill collar as the outer barrel. These collars are the same as those used elsewhere in the BHA. The core barrel can remain motionless relative to the incoming core while the bit and the outer core barrel rotate. Cores are cut by rotating and lowering the entire drill string. The cutters of the core bit and the circulation of seawater remove rock or sediment ahead of the bit but leave a central stub that becomes the core.

\section{Drilling Parameters}

Because water used to lubricate the drill bit is not recirculated, cuttings are lost onto the sea floor and cannot be examined. However, in uncored or unrecovered intervals, it is sometimes possible to deduce some information about sedimentary stratification from an examination of the behavior of the drill string as observed and recorded at the rig floor.

There are, however, a number of factors that influence the rate of penetration. First, the driller may vary the weight on the drill bit between 5,000 and $40,000 \mathrm{lb}$. Typically weight on bit is increased gradually downhole. Second, the rate of rotation of the bit can be varied between about 10 and 160 revolutions per minute (RPM). Finally, the rate at which seawater is circulated out the bottom of the pipe can be adjusted over a wide range. Thus, it is not always straightforward to relate rotating time directly to the hardness of the formation.

\section{SHIPBOARD SCIENTIFIC PROCEDURES}

\section{Numbering of Sites, Holes, Cores, and Samples}

ODP drill sites are numbered consecutively from the first site drilled by Glomar Challenger in 1968. Site numbers are slightly different from hole numbers. A site number refers to one or more holes drilled while the ship is positioned over a single acoustic beacon. Several holes may be drilled at a single site by pulling the drill pipe above the sea floor (out of one hole), moving the ship a short distance from the previous hole, and then drilling another hole.

For all ODP drill sites, a letter suffix distinguishes each hole drilled at the same site. For example, the first hole takes the site number with suffix $\mathrm{A}$, the second hole takes the site number with suffix B, and so forth. This procedure is different from that used by the Deep Sea Drilling Project (Sites 1-624) but it prevents the ambiguity between site and hole number designations that existed previously.

The cored interval is measured in meters below the sea floor (mbsf) (Fig. 1). The depth interval of an individual core is the depth below the sea floor at which the coring began for that particular core, to the depth below the sea floor at which the coring operation ended. The maximum coring interval is $9.7 \mathrm{~m}$, the maximum lineal capacity of a core barrel. The coring interval may, however, be shorter. Cored intervals are not necessarily adjacent to each other but may be separated by drilled intervals. In soft sediment, the drill string can be washed ahead with the core barrel in place, but not recovering sediment, by pumping water down the pipe at high pressure to wash the sediment out of the way of the bit and up the space between the drill pipe and wall of the hole. However, if thin, hard rock layers are present, it is possible to get spotty sampling of these resistant layers within the washed interval.

Cores taken from a hole are numbered sequentially from the top of the hole downward. Maximum full recovery for a single core is $9.7 \mathrm{~m}$ of sediment or rock in a plastic liner $(6.6 \mathrm{~cm}$ in diameter). In addition, a sample about $0.2 \mathrm{~m}$ long (without a plastic liner) is recovered from below the core by the core catcher. The core catcher is a device at the bottom of the core barrel that prevents the core from sliding out when the barrel is retrieved from the hole. The core, in the plastic liner, is cut into 1.5 -m-long sections that are numbered sequentially from the top of the core (Fig. 2). With full recovery, the sections are numbered from 1 through 7, the last section being shorter than 1.5 $\mathrm{m}$. For sediments and sedimentary rocks, the core-catcher sample is placed below the last section and treated as a separate section.

When recovery is less than $100 \%$, whether or not the recovered material is contiguous, the empty interval at the top of the core is discarded and $1.5-\mathrm{m}-$ long sections are numbered sequentially, starting with Section 1 at the top of the recovered interval. There are as many sections as needed to accommodate the length of the core recovered (Fig. 2); for example, $3 \mathrm{~m}$ of core sample in a plastic liner will be divided into two 1.5 -m-long sections. Sections are cut starting at the top of the recovered core, and the last section may be shorter than the normal $1.5-\mathrm{m}$ length. If, after the core has been split, fragments separated by a void appear to have been contiguous in situ, a note is made in the description of the section. All voids, whether real or artificial, are preserved during curation and noted in the barrel sheets.

Samples are designated by distances in centimeters from the top of each section to the top and bottom of the sample interval in that section. A full identification number for a sample consists of the following information: (a) leg, (b) site, (c) hole, (d) 


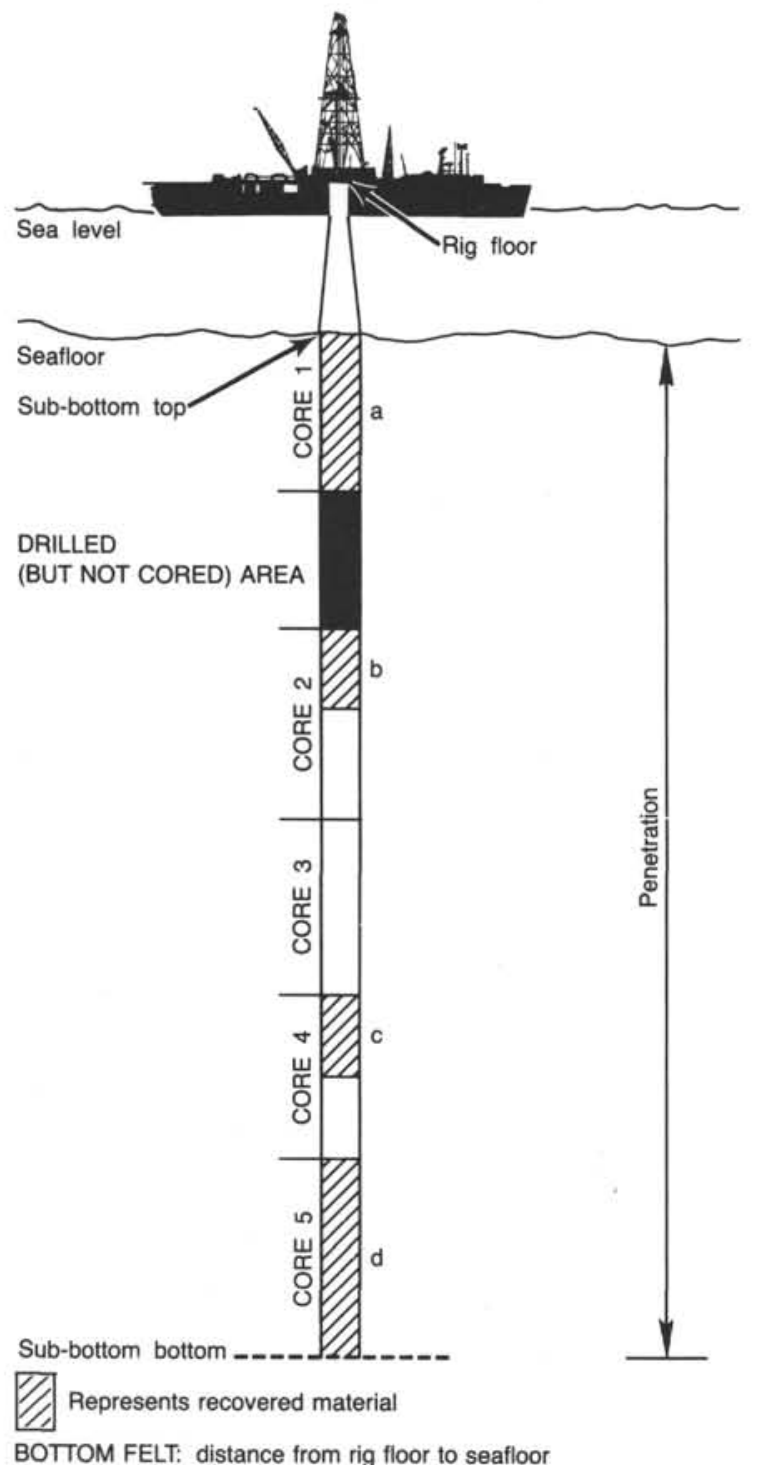

TOTAL DEPTH: distance from rig floor to bottom of hole (sub-bottom bottom)

PENETRATION: distance from seafloor to bottom of hole (sub-bottom bottom)

NUMBER OF CORES: total of all cores recorded including cores with no recovery

TOTAL LENGTH

OF CORED SECTION: distance from sub-bottom top to sub-bottom bottom minus drilled (but not cored) areas in between

TOTAL CORE RECOVERED: total from adding a, b, $c$, and $d$ in diagram

$\begin{aligned} & \text { CORE RECOVERY (\%): } \text { equals TOTAL CORE } \\ & \text { RECOVERED } \\ & \text { divided by } \\ & \text { TOTAL LENGTH OF } \\ & \text { CORED SECTION } \\ & \text { times } 100\end{aligned}$

Figure 1. Diagram illustrating terms used in discussion of coring operations and core recovery.

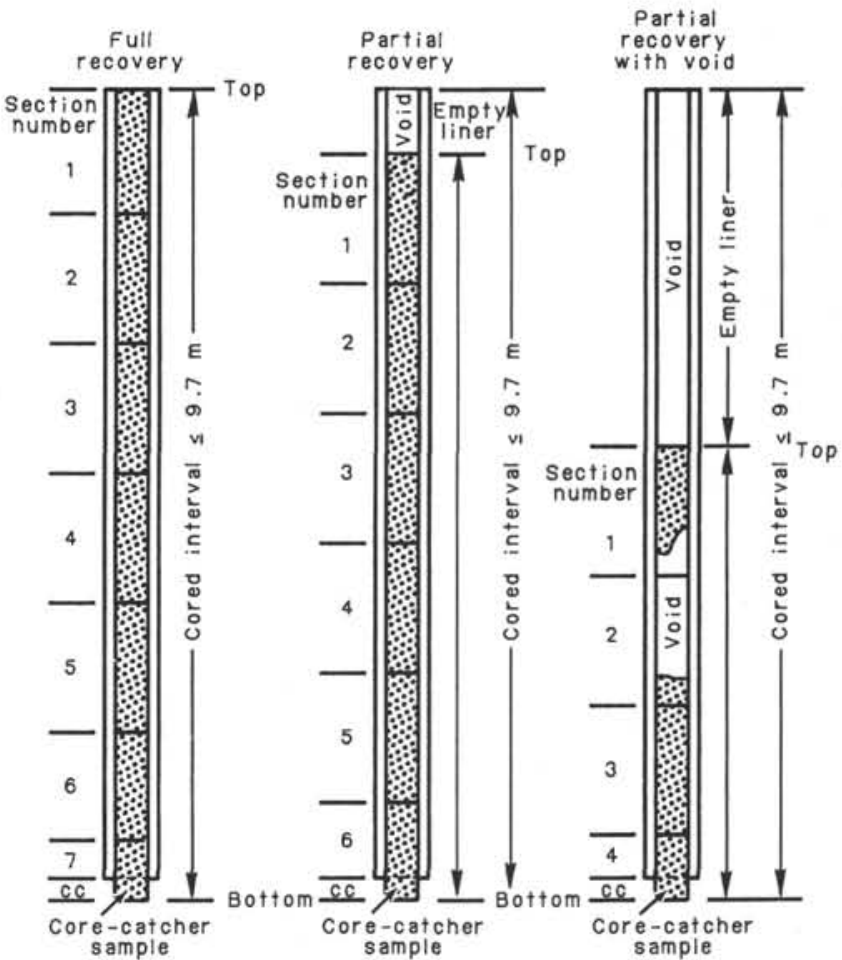

Figure 2. Diagram showing procedure for cutting and numbering recovered core sections.

core number and type (see below), (e) section, and (f) interval in centimeters. For example, the sample identification number "116-719A-17X-2, 98-100 cm" means that a sample was taken between 98 and $100 \mathrm{~cm}$ below the top of Section 2 of the Extended Core Barrel-drilled Core 17, from the first hole drilled at Site 719 during Leg 116. A sample from the core catcher (CC) of this core would be designated "116-719A-17X, CC, 8-9 cm."

The depth below the sea floor for a sample numbered, for example, "116-719A-17X-2, 98-100 cm" is the sum of the depth to the top of the cored interval for Core $17(146.7 \mathrm{~m})$ plus the $1.5 \mathrm{~m}$ included in Section 1 plus the $98 \mathrm{~cm}$ below the top of Section 2. The sample in question is therefore located at $148.88 \mathrm{~m}$ sub-bottom which, in principle, is the sample sub-sea-floor depth (sample requests should refer to a specific interval within a core section, rather than sub-bottom depths in meters).

In Core 719A-28X, we cored $9.5 \mathrm{~m}$ but recovered $10.15 \mathrm{~m}$ (see Site 719 chapter, this volume). That this recovery is greater than the interval cored is attributed to soft sediment expanding up into the barrel because the diameter of the core drilled was slightly greater than the diameter of the core liner. To assign sub-bottom depths to Core $719 \mathrm{~A}-28 \mathrm{X}$, we apportioned the 10.15 $\mathrm{m}$ recovered equally to the $9.5-\mathrm{m}$ drilled interval (251.2-260.7 mbsf).

All ODP core and sample identifiers include core type. The following abbreviations are used: $\mathrm{R}=$ rotary barrel $(\mathrm{RCB}) ; \mathrm{H}$ $=$ advanced piston core (APC), $\mathrm{X}=$ extended core barrel (XCB); and I = in-situ water sample.

\section{Core Handling}

As soon as a core was retrieved on deck, a sample was taken from the core catcher and taken to the paleontological laboratory for an initial assessment of the age of the sample.

The core was then placed on the long horizontal rack on the catwalk and gas samples were taken by piercing the core liner and withdrawing gas into a vacuum-tube sampler. Voids within 
the core were sought as sites for the gas sampling. The gas samples were analyzed immediately, as part of the shipboard safety and pollution-prevention program. Next, the core was marked into section lengths, each section was labeled, and the core was cut into sections. Interstitial water (IW) and organic geochemistry (OG) whole-round samples were then taken. Each section was sealed top and bottom by gluing on a plastic cap, blue to identify the top of a section and clear for the bottom. A yellow cap was placed on both section ends from which a whole-round core sample had been removed. The caps were usually attached to the liner by coating the end of the liner and the inside rim of the end cap with acetone, though we elected to tape the end caps in place without acetone at geochemically interesting portions.

The cores were then carried into the laboratory, where the sections were again labeled using an engraver to mark the full designation of the section. The length of core in each section and the core-catcher sample was measured to the nearest centimeter, and this information was logged into the shipboard corelog data base program.

The cores were allowed to warm to room temperature (approximately $4 \mathrm{hr}$ ) before they were split. During this time, the whole-round sections were run through the gamma-ray attenuation porosity evaluation (GRAPE), a device for estimating bulk density and porosity (see discussion below; Boyce, 1976), and through the Bartington Instruments model MS-1 magnetic susceptibility meter. After the cores had equilibrated to room temperature but before being split, thermal conductivity measurements were made using the needle probe method.

Cores of relatively soft material were split lengthwise into work and archive halves. Depending on the degree of induration the softer cores were split with a wire or a saw, using shipboard water. In soft sediments, some smearing of material can occur so, to minimize contamination, scientists analyzing samples should avoid using the very near-surface part of the split core. Harder cores were split with a band saw or diamond saw. Where the cored material was of uneven diameter or did not fill the entire diameter of the core liner, the diameter of the split core was measured with calipers at all significant points to provide the path-length data needed later to interpret the GRAPE data. These caliper data were recorded on the visual core description forms.

The work half was sampled for both shipboard and shorebased laboratory studies. Each extracted sample was listed by location and the name of the investigator receiving the sample and entered into the sample-logging computer program. Records of all samples are kept by the Curator at ODP. The extracted samples were sealed in plastic vials or bags and labeled. Samples were routinely taken for shipboard analysis of sonic velocity by the Hamilton Frame method, water content by gravimetric analysis, percent calcium carbonate $\left(\mathrm{CO}_{2}\right.$ coulometer), and other purposes. Preliminary results from many of these samples are reported in the site chapters.

The archive half was described visually. Smear slides were made from samples taken from the archive half, and were supplemented by thin sections taken from the work half. Additionally, remanent magnetization measurements were made on all archive sections with lengths greater than about $70 \mathrm{~cm}$, to provide a reconnaissance of magnetic properties. In addition, these sections were also demagnetized in an alternating magnetic field with a strength of $9 \mathrm{mT}$ and remeasured. The archive half was then photographed with both black-and-white and color film, a whole core at a time.

Both halves were then put into labeled plastic tubes, sealed, and transferred to cold-storage space aboard the drilling vessel. Leg 116 cores were taken from the ship via refrigerated transport to cold storage at the Gulf Coast Repository, at ODP headquarters, Texas A\&M University, College Station, Texas.

\section{SEDIMENT CORE DESCRIPTION FORMS (BARREL SHEETS)}

The core description forms (Fig. 3), or barrel sheets, summarize the data obtained during shipboard analysis of each core. The following discussion explains the ODP conventions used in compiling each part of the core description form as well as the exceptions to these procedures adopted by Leg 116 scientists.

\section{Core Designation}

Cores are designated using site, hole, core number, and type as previously discussed (see "Numbering of Sites, Holes, Cores, and Samples" above). In addition, the cored interval is specified in terms of meters below sea level (mbsl) and meters below sea floor (mbsf). On Leg 116, these depths were based on the drillpipe measurement, as reported by the SEDCO/FOREX Coring Technician and the ODP Operations Superintendent.

\section{Age Data}

Microfossil abundance, preservation, and zone assignment, as determined by the shipboard paleontologists, appear on the core description form under the heading "Biostrat. Zone/Fossil Character." The geologic age determined from the paleontology appears in the "Time-Rock Unit" column.

On Leg 116, calcareous nannofossils and planktonic and benthic foraminifers provided the majority of age determinations. Detailed information on the zonations and terms used to report abundance and preservation appear below (see "Biostratigraphy" section, this chapter).

\section{Paleomagnetic, Physical Property, and Chemical Data}

Columns are provided on the core description form to record paleomagnetic results, location of physical properties samples (density, porosity, velocity, and thermal conductivity), and chemical data (percentage of $\mathrm{CaCO}_{3}$ determined using the $\mathrm{CO}_{2}$ coulometer). Additional information on shipboard procedures for collecting these types of data appears below (see "Paleomagnetism", "Physical Properties", and "Geochemistry" sections, this chapter).

\section{Graphic Lithology Column}

The lithologic classification scheme presented here is represented graphically on the core description forms using the symbols illustrated in Figure 4.

It is important to realize that the ODP conventions for graphically representing sediment types do not distinguish a sequence of mixed components (e.g., $50 \%$ calcareous ooze, $50 \%$ clay) from a sequence of thin $(<10 \mathrm{~cm})$ interbedded sediments of each component (e.g., alternating calcareous ooze and clay layers).

\section{Sediment Disturbance}

Core deformation probably occurs during one of three different steps at which the core can suffer stresses sufficient to alter its physical characteristics: cutting, retrieval (with accompanying changes in pressure and temperature), and core handling.

The coring technique, which uses a $25-\mathrm{cm}$-diameter bit with a 6-cm-diameter core opening, may result in extreme disturbance of the recovered core material. This is annotated in the "Drilling Disturbance" column on the core description form using the symbols in Figure 5, as explained below.

The following disturbance categories are recognized for soft and firm sediments:

1. Slightly deformed: bedding contacts bent, some rotation of segments of core. 


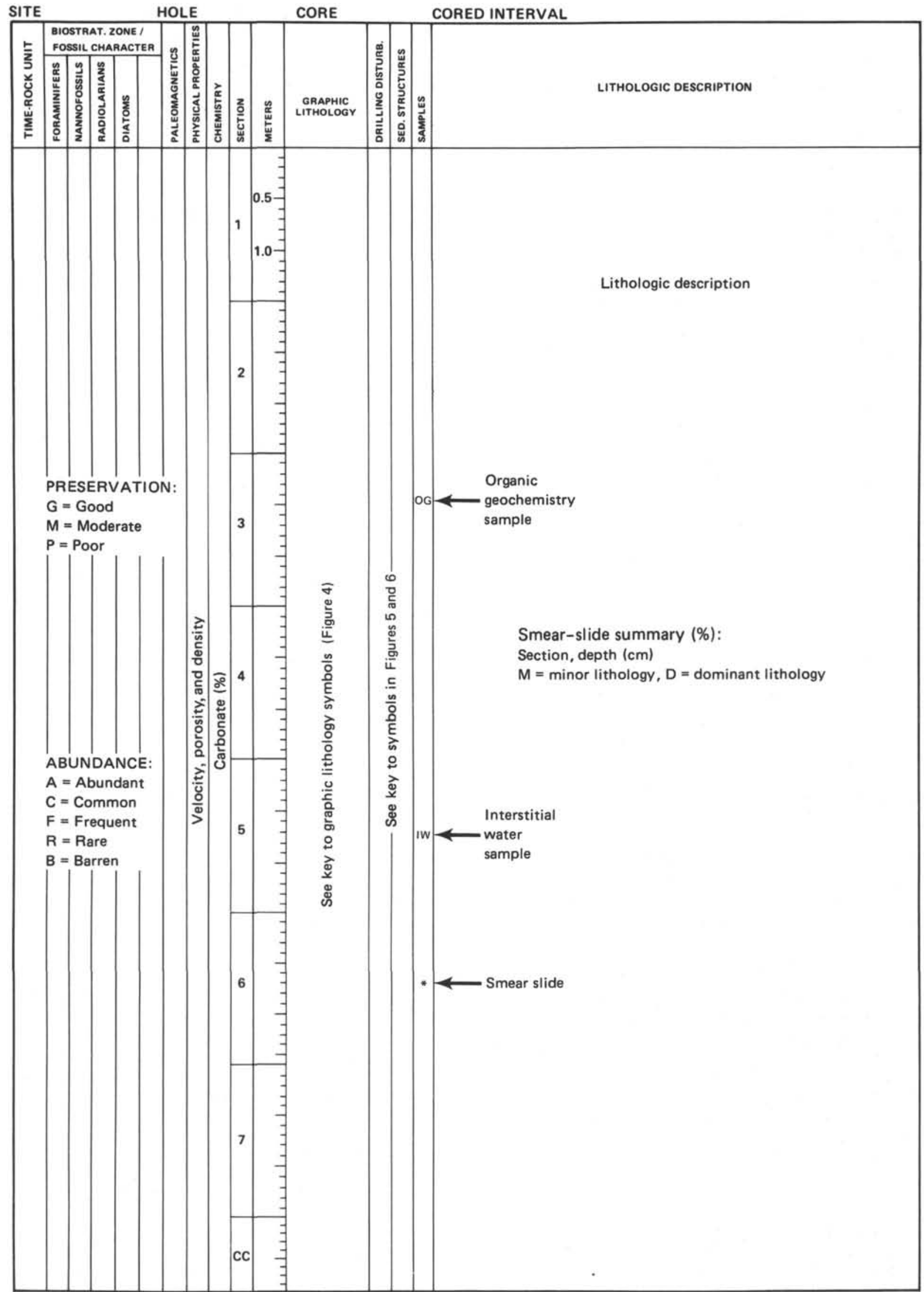

Figure 3. Core description form (barrel sheet) used for sediments and sedimentary rocks. 
TRANSITIONAL BIOGENIC TERRIGENOUS SEDIMENTS
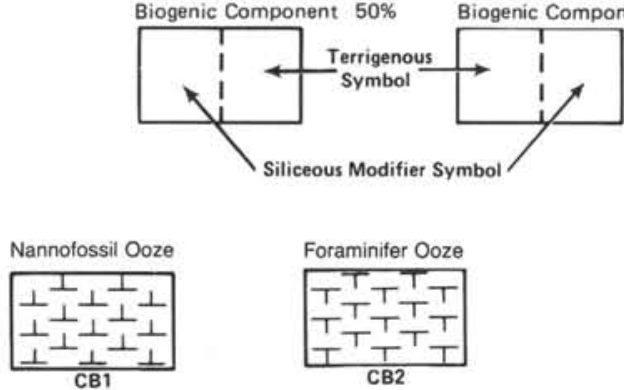

$$
\begin{aligned}
& \text { Foraminifer Ooze } \\
& \begin{array}{l}
T T T T T \\
T T_{T}^{T} T T \\
T T_{T}
\end{array}
\end{aligned}
$$
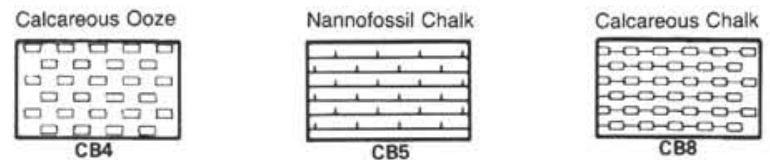

CB4

CB5

CB:
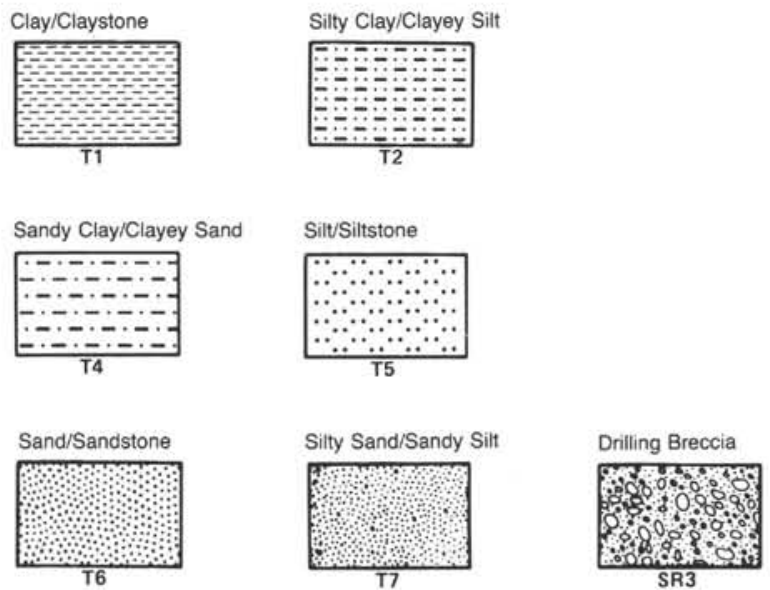

Figure 4. Key to lithologic symbols used in "Graphic Lithology" column on core description forms (see Fig. 3).

2. Moderately deformed: bedding contacts are bowed downward, biscuits are common but sediment in biscuits is relatively undisturbed.

3. Highly disturbed: bedding is highly deformed, biscuits are abundant and tilted, bent or broken.

4. Soupy: sediment has liquified and flowed in the core barrel, commonly forms matrix for biscuits.

\section{Sedimentary Structures}

In soft, and even in firm sediments, it may be extremely difficult to distinguish between natural structures and structures created by the coring process. Where such structures were observed they are indicated in the "Sedimentary Structure" column of the core description forms. A key to the structural symbols used on Leg 116 is given in Figure 6. A series of diagonal lines with the letters "GE" represents a scaly surface developed in silty units and is attributed to gas escape. The letters "CF" signify a ferro-manganiferous chemical front.

\section{Samples}

The position of samples taken from each core for shipboard analysis is indicated in the "Samples" column in the core description form. An asterisk $\left({ }^{*}\right)$ indicates the location of smearslide samples. The symbols IW and OG designate whole-round interstitial water, and frozen organic geochemistry samples, respectively.

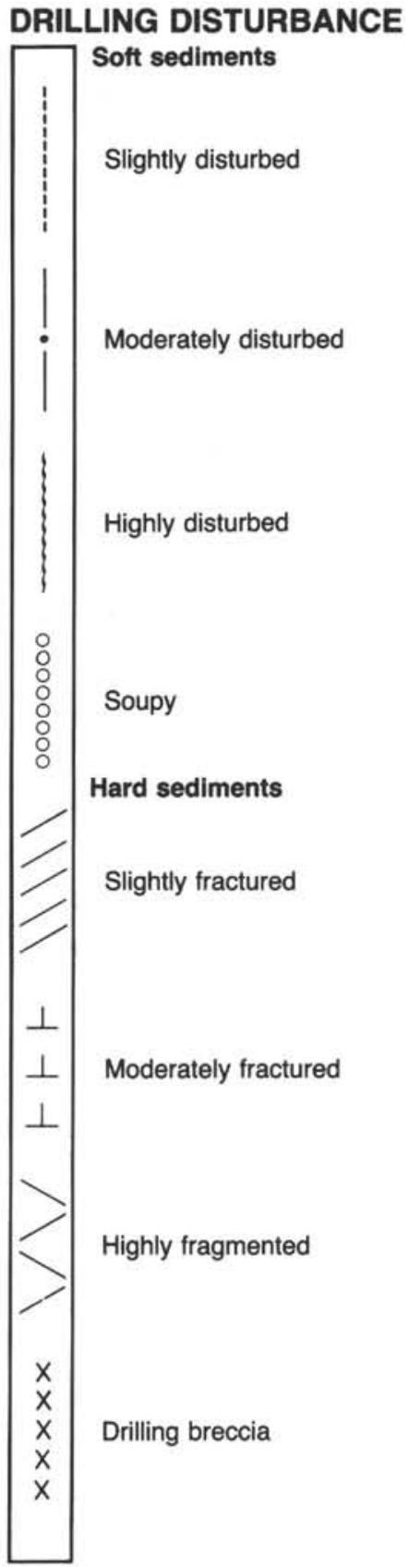

Figure 5. Drilling disturbance symbols used on Leg 116 core description forms.

The positions of samples for routine physical properties analyses are indicated by a dot in the "Physical Properties" column; the location of samples for $\mathrm{CO}_{2}$ Coulometer analyses are indicated by a dot in the "Chemistry" column (most of these samples are taken from the working half of the core, and generally correspond to smear-slide locations in the archive half, although this is not always the case. Some whole-round samples were taken on Leg 116). Carbonate content and physical properties data are given beside the sample dots.

\section{Lithologic Description-Text}

The lithologic description which appears on each core description form consists of two parts: (a) a brief heading in capital letters that lists the dominant lithologies in the core, and (b) a detailed description of all the lithologies present in the core. 


\begin{tabular}{|c|c|}
\hline \multicolumn{2}{|c|}{ SEDIMENTARY STRUCTURES } \\
\hline & Parallel laminae \\
\hline & Load casts \\
\hline & Sharp contact \\
\hline & Scoured, sharp contact \\
\hline & Gradational contact \\
\hline & Fining-upward bed \\
\hline$\therefore$ & Indistinct fining-upward bed \\
\hline$\nabla$ & Coarsening-upward bed \\
\hline$?$ & Bioturbation, minor ( $<30 \%$ surface area) \\
\hline 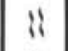 & Bioturbation, moderate ( $30-60 \%$ surface area) \\
\hline iil & Bioturbation, strong ( $>60 \%$ surface area) \\
\hline ○ & $\begin{array}{l}\text { Secondary structures } \\
\text { Concretions }\end{array}$ \\
\hline & Compositional structures \\
\hline M. & Gas expansion \\
\hline$F \cdot$ & Chemical front \\
\hline
\end{tabular}

Figure 6. Sedimentary structure symbols for sediments and sedimentary rocks.

\section{Smear-Slide Summary}

A table summarizing smear-slide and thin-section data appears on each core description form. The section and interval from which the sample was taken is noted, as well as identification as a dominant (D) or minor (M) lithology in the core. The percent of all identified components (totalling 100\%) is listed. As explained below, these data, combined with $\mathrm{CaCO}_{3}$ measurements done on board, are used to classify the recovered material. It is important to note that smear-slide estimates are not corrected to $\mathrm{CaCO}_{3}$ content, thus the smear-slide data are erroneous in some cases.

\section{OBTAINING SAMPLES}

Potential investigators wishing to obtain samples should refer to the ODP-NSF Sample Distribution Policy. Sample request forms may be obtained from the Curator, Ocean Drilling Program, Texas A\&M University, College Station, Texas 778433469. Requests must be as specific as possible: include site, hole, core, section, interval within a section, and volume of sample required.

\section{SEDIMENT CLASSIFICATION}

The classification system used during Leg 116 was a modification of that devised by the Joint Oceanographic Institutions for Deep Earth Sampling (JOIDES) former Panel on Sedimentary Petrology and Physical Properties $\left(\mathrm{SP}^{4}\right)$ and adopted for use by the JOIDES Planning Committee in March 1974. Core descriptions, smear-slide descriptions, and $\mathrm{CO}_{2}$ coulometer (percentage of $\mathrm{CaCO}_{3}$ ) data, all obtained on the ship, served as the bases of the graphic core descriptions presented on the core description forms at the end of each site chapter.

Sediment and rock names were defined solely on the basis of composition and texture. Composition is most important for description of those deposits more characteristic of open marine conditions, with texture becoming more important for the classification of hemipelagic and nearshore facies. These data were primarily determined on the ship by: (a) visual estimates in smear slides and thin sections using microscopes; (b) visual observation using a hand lens, and (c) unaided visual observation. Calcium carbonate content was estimated in smear slides and by using the $\mathrm{CO}_{2}$ coulometer technique. Other geologic features determined were color, sedimentary structures, and degree of lithification.

\section{Color}

Colors of the recovered material were determined with Munsell soil color charts. Colors were determined immediately after the cores were split and while they were still wet. Information on core colors is given in the "Lithologic Description" text on the core description forms (Fig. 3).

\section{Firmness}

The determination of induration is highly subjective, but the categories used on Leg 116 are thought to be practical and significant. The criteria of Gealy et al. (1971) were used for calcareous deposits with more than $50 \% \mathrm{CaCO}_{3}$; subjective estimate of behavior in core cutting was used for transitional calcareous sediments with less than $50 \% \mathrm{CaCO}_{3}$, pelagic, hemipelagic, and terrigenous sediments. There are three classes of firmness for calcareous sediments:

1. Soft: sediments that have little strength and are readily deformed under the finger or broad blade of the spatula are termed ooze.

2. Firm: partly lithified ooze or friable limestone is called chalk. Chalks are readily deformed under the fingernail or the edge of a spatula blade.

3. Hard: Indurated chalk; Limestone is restricted to nonfriable cemented rock.

There are only two classes of firmness for noncalcareous sediments:

1. Soft: sediment core may be split with a wire cutter. soft terrigenous sediment, pelagic clay, and transitional calcareous biogenic sediments are termed sand, silt, clay, or mud.

2. Hard: the core is hard (i.e., consolidated or well indurated) if it must be cut with a band saw or diamond saw. For these materials, the suffix -stone is added to the soft-sediment name (e.g., sandstone, siltstone, claystone, mudstone).

\section{BASIC SEDIMENT TYPES}

Adapted and modified from the standard DSDP sediment classification scheme (Ross et al., 1978), the following defines compositional class boundaries and the use of qualifiers in the lithologic classification scheme used during Leg 116 (Fig. 7).

\section{Pelagic Clay}

Pelagic clay is a fine-grained sediment that has settled through the water column, normally at very slow rates. This type of sediment has often been termed brown clay or red clay. Sediments interpreted as pelagic clay on Leg 116 have been classified under terrigenous sediments.

\section{Calcareous Biogenic Sediments}

Calcareous biogenic sediment is distinguished by a biogenic $\mathrm{CaCO}_{3}$ content in excess of $30 \%$. There are two classes: (a) $\mathrm{Pe}$ lagic calcareous biogenic sediments which contain $65-100 \%$ biogenic $\mathrm{CaCO}_{3}$ (less than $30 \%$ silt and clay), and (b) Transitional calcareous biogenic sediments which contain $30-60 \% \mathrm{CaCO}_{3}$ 


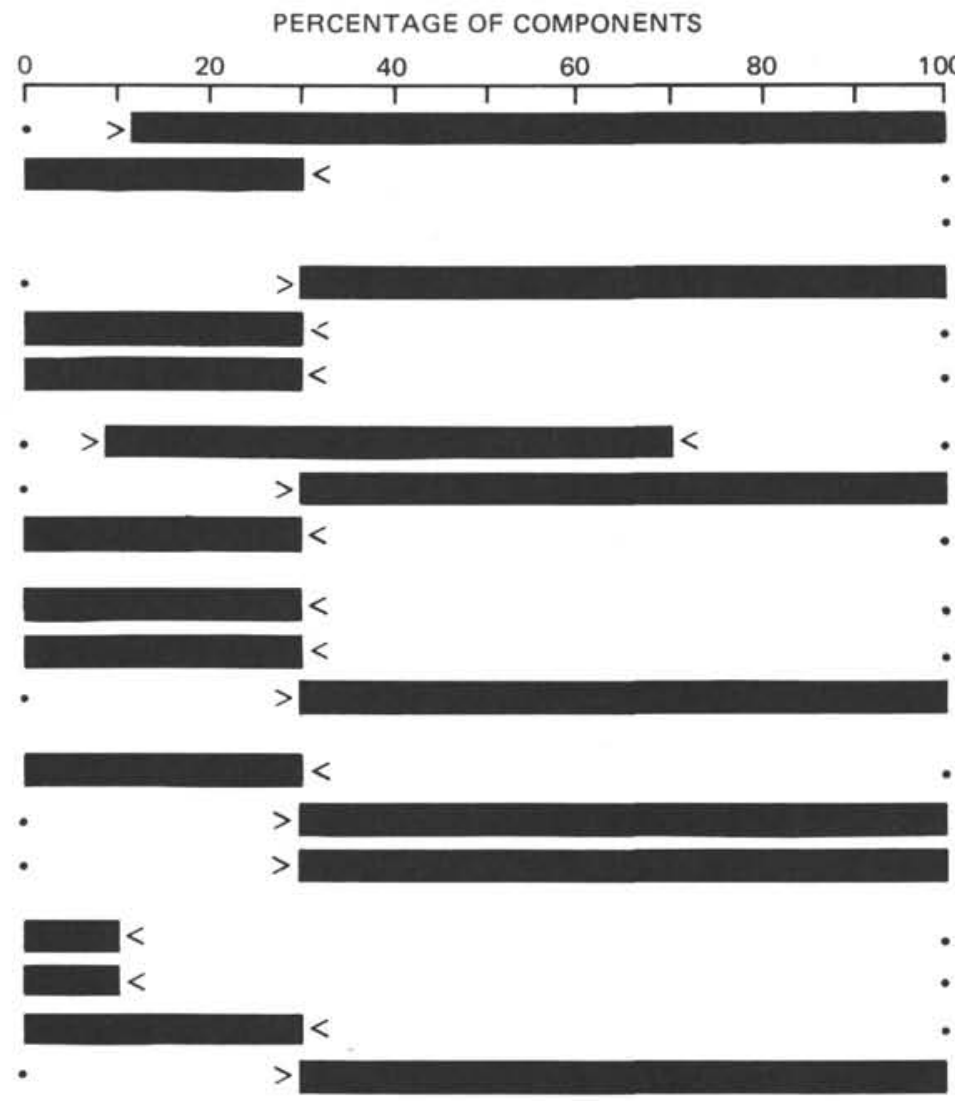

Figure 7. Summary chart for lithologic classification of sediments.
COMPONENT

NOMENCLATURE

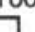

Authigenic components

- Siliceous skeletons

- $\mathrm{CaCO}_{3}$

Siliceous skeletons

- Silt and clay

- $\mathrm{CaCO}_{3}$

Siliceous skeletons

Silt and clay

- $\mathrm{CaCO}_{3}$

- Siliceous skeletons

- Silt and clay

$\mathrm{CaCO}_{3}$

- Siliceous skeletons

Silt and clay

$\mathrm{CaCO}_{3}$

- Authigenic components

- Siliceous skeletons

- $\mathrm{CaCO}_{3}$

Terrigenous and volcanic detritus
SEDIMENT TYPE

Pelagic clay

Pelagic biogenic siliceous

Transitional biogenic siliceous

Pelagic biogenic calcareous

Transitional biogenic calcareous

Terrigenous sediments (greater than $30 \%$ silt and clay). Lithologic names given to these classes of sediment are also dependent on the degree of sediment consolidation, as shown in Figure 4. Sediments belonging to other classification categories, but which contain $10-30 \%$ of calcareous components, are given the modifier "calcareous" (or "foraminifer" or "nannofossil" as appropriate). A content of less than $10 \% \mathrm{CaCO}_{3}$ was ignored in the sediment nomenclature.

1. Pelagic biogenic calcareous sediments: (a) Soft: calcareous oozes; (b) Firm: chalk; and (c) Hard: indurated chalk. The term "Limestone" is restricted to cemented rocks.

Composition qualifiers: Principal components are nannofossils and foraminifers. One or two qualifiers were commonly used, for example:

\begin{tabular}{cl}
\hline Foraminifers (\%) & \multicolumn{1}{c}{ Name } \\
\hline$<10$ & Nannofossil ooze, chalk, limestone \\
$10-25$ & Foraminifer-nannofossil ooze \\
$25-50$ & Nannofossil-foraminifer ooze \\
$>50$ & Foraminifer ooze \\
\hline
\end{tabular}

2. Transitional biogenic calcareous sediments: (a) Soft: marly calcareous (or nannofossil, foraminifer, etc.) ooze; (b) Firm: marly chalk; and (c) Hard: marly limestone.

\section{Terrigenous Sediments}

Sediments falling into this portion of the classification scheme are divided into textural groups on the basis of relative propor- tions of three grain-size constituents, i.e., sand, silt, and clay, using the terminology of Shepard (1954). The size limits for these constituents are those defined by Wentworth (1922) (Fig. 8).

Ten major textural groups are recognized on the accompanying triangular diagram (Fig. 9). Although differentiated on the Visual Core Description forms, clayey silt/silty clay, clayey sand/ sandy clay and sandy silt/silty sand are not differentiated on the barrel sheets in this volume. The reader is referred to the primary data for this information.

Terrigenous sediments containing $10-30 \% \mathrm{CaCO}_{3}$ receive the modifier "calcareous." Consolidated sediments in the same textural groups receive the modifier "-stone" (e.g., "silty clay" becomes "silty claystone").

\section{BIOSTRATIGRAPHY}

During Leg 116, age determination was based on the study of each core-catcher assemblage and on specially selected shipboard paleontological samples. Nannofossils, planktonic and benthonic foraminifers, diatoms, and radiolarians were used as age indicators.

\section{Foraminifer Abundance and Preservation}

The low-latitude zonal scheme of Bolli and Saunders (1985) was adopted for the planktonic foraminifers biostratigraphy. However, the letter nomenclature of Blow (1969) was used following the correlation indicated by Bolli and Saunders (1985).

The abundance of foraminifers contained in sediment samples is defined as follows: 


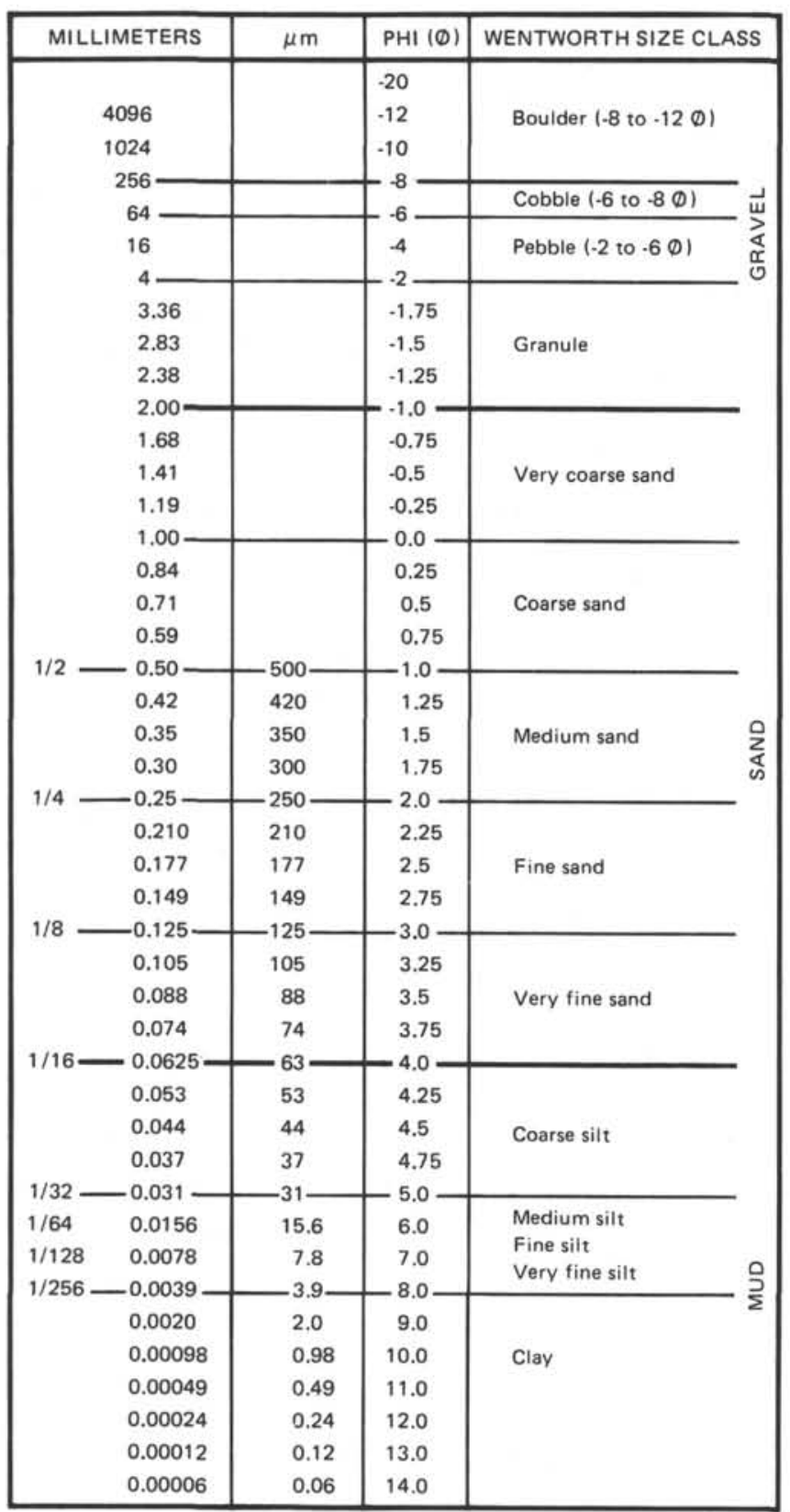

Figure 8. Grain-size categories used for classification of terrigenous sediments (from Wentworth, 1922).
A - abundant (when the residue over $63 \mu \mathrm{m}$ consists only of foraminifers);
C - common (when foraminifers are more common than the detrital fraction);
F - few (when detrital fraction exceeds the foraminifer content);
R - rare (when foraminifers are diluted in a detrital resi- due).

Percentages were estimated by visual examination.

Preservation includes the effects of diagenesis, abrasion, and/or dissolution (which was the most striking on this leg):

G - good (dissolution effect rare);

M - moderate (dissolution common but minor);

$\mathrm{P} \quad$ - poor (dissolution effect strong).

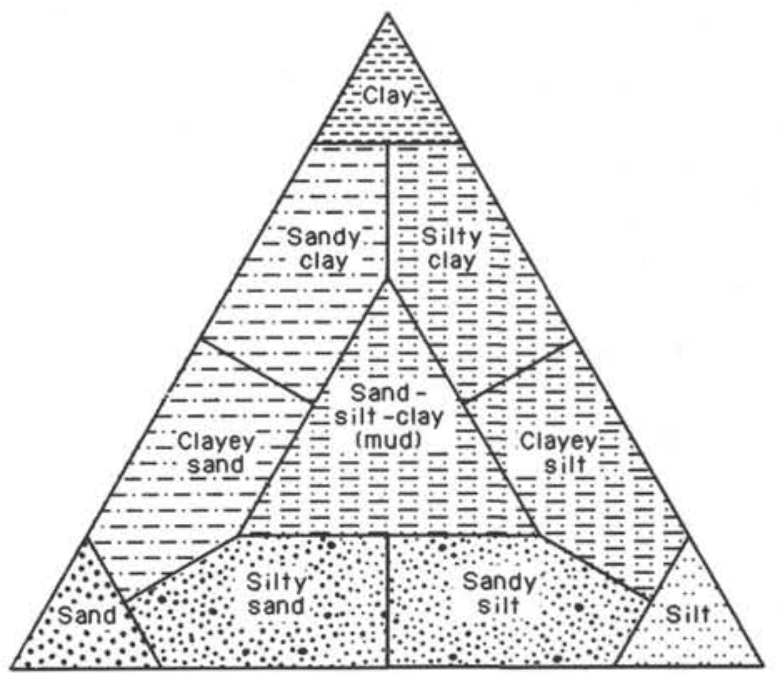

Figure 9. Triangular diagram showing classification scheme used for terrigenous sediments and sedimentary rocks on Leg 116. Lithologic symbols in regions of the regions of the diagram were used on visual core description forms (after Shepard, 1954).

\section{Nannofossil Abundance and Preservation}

Nannofossil slides were prepared from unprocessed sample material. Examination was done at a magnification of $1250 \times$. Abundances are presented semiquantitatively and have the following approximate values:
AA - very abundant (dominant); $>80 \%$ of a rich assem- blage
A - abundant; >100 specimens encountered
C - common; approximately $20-100$ specimens encoun- tered
F - few; approximately 5-20 specimens encountered
$\mathrm{R}$ - rare; $2-5$ specimens encountered
$\mathrm{r}$ - very rare; $1-2$ specimens encountered

This representation is somewhat unconventional, however, owing to the very large spread of abundance of nannofossils in the turbidite sequences cored on this leg; the above representation was found most suitable for abundances ranging from 1 or 2 specimens per 15-min search, to low-diversity (solution concentrated) redeposited pelagic carbonate.

Preservation is represented by the conventional code, i.e.,

G - good; little or no evidence of solution and/or overgrowth

M - moderate; some dissolution and/or overgrowth, but nearly all specimens can be identified

P - dissolution and/or overgrowth on nearly every specimen. Many specimens cannot be identified

\section{Diatom Abundance and Preservation}

Diatom frustules were cleaned and mounted following standard procedure (Kaczmarska, 1985). Age assignments followed the zonation scheme by Burckle (1972) and Barron (1985). Abundance and preservation were defined as follows:

A - abundant; at least one specimen per field of view under $40 \times$ objective

C - common; at least one specimen per one transect under $40 \times$ objective 
F - few; one specimen per every 3-4 transects under $40 \times$ objective

R - rare; a few specimens per slide

G - good preservation; little or no evidences of dissolution

M - moderate preservation; dissolution evident but specific, identification still possible

$\mathrm{P}$ - poor preservation; specific designation impossible

\section{Radiolarian Abundance and Preservation}

The low-latitude radiolarian zonation used during Leg 116 is that of Sanfilippo et al. (1985). The sample preparation procedures used here are also described in that work.

\section{PALEOMAGNETISM}

Two types of measurements, volume magnetic susceptibility and remanent magnetization, were routinely made during Leg 116 on most cores to assess the magnetic properties of the recovered sediments. Volume magnetic susceptibility measurements were made on whole, unsplit sections of core using a Bartington Instruments model MS-1 magnetic susceptibility meter with an 80 -mm sensing loop. Whole-round core sections were measured with a spacing of $5 \mathrm{~cm}$. The magnetic susceptibility, $k$, is a dimensionless scalar quantity related to the applied magnetic field vector, $H$, by

$$
M=k H,
$$

where $M$ is the magnetization vector induced in the material within the field. Because all of the shipboard data processing and plotting routines have been designed for cgs units, these are used in the site reports. A conversion to standard SI units is accomplished simply by multiplication of the susceptibility values by a constant, $k_{\mathrm{cgs}}=4 \pi k_{\mathrm{si}}$. The Bartington susceptibility meter has a sensitivity of $1 \times 10^{-7} \mathrm{cgs}$, but on Leg 116 the weakest sediments measured had susceptibilities more than an order of magnitude greater, and most displayed values 2 to 3 orders of magnitude higher.

Remanent magnetism measurements were also made at a spacing of $5 \mathrm{~cm}$, but on the archive halves of core sections with lengths greater than about $70 \mathrm{~cm}$. These measurements were made with a three-axis pass-through cryogenic magnetometer built by $2 \mathrm{G}$ Enterprises. Within the magnetometer is situated a set of coils that allow three-axis alternating field (AF) demagnetization to be performed on the core sections without removing the coils from the magnetometer. This coil system provides AF fields of up to $9 \mathrm{mT}$ in steps of $1 \mathrm{mT}$. Most cores examined on Leg 116 were measured only at the NRM and $9 \mathrm{mT}$ steps.

The pass-through magnetometer was designed to be used primarily on APC cores containing minimal drilling disturbance. Unfortunately, shallow sub-surface sands and silts made it impossible to use the APC below the mud-line core in any of the holes drilled on Leg 116. The XCB and RCB drilling techniques produced a pervasive rotational deformation of the core material that rendered the remanent magnetic measurements of limited usefulness. Commonly, the sediment was broken into biscuits a few centimeters in thickness, which had been rotated about a vertical axis. In many cases these biscuits were separated by fine-grained layers that are probably a slurry of drilling debris. Sometimes the biscuits had been not only rotated, but also tilted. Because the sensing region of the cryogenic magnetometer has a half-width of $15 \mathrm{~cm}$, most measurements averaged the magnetizations of several biscuits. In general, this averaging causes the vertical magnetization components of individual biscuits to constructively add while the horizontal components tend to partially cancel one another. This results in a steepening of the measured inclination values that may well account for the larger-than-expected inclination values observed during Leg 116. Consequently, the pass-through remanent magnetic measurements must be interpreted with caution. Despite this problem, extensive remanent magnetization measurements were undertaken on Leg 116 primarily to serve as a reconnaissance of magnetic properties, intensity in particular, and for comparison with the volume magnetic susceptibility measurements.

All measurements of magnetic remanence made during Leg 116 displayed a strong, steeply-dipping overprint that appears to result from a strong magnetic field generated by the drill pipe, core barrel, or both. In fact, Leg 116 sediments were so strongly magnetic and prone to the acquisition of an overprint that a significant percentage of core sections had intensities too large to be measured by the cryogenic magnetometer. Even after AF demagnetization at $9 \mathrm{mT}$, a few sections were still too strongly magnetic to measure. Demagnetizing the core material with the maximum AF field available $(9 \mathrm{mT})$ only partially removed this overprint. In an attempt to overcome or at least reduce this problem, the XCB core barrel was demagnetized on several occasions prior to coring. Each time, however, when the barrel was returned to the surface it was found to be strongly magnetized once again. As a result, there was no perceptible difference in the magnetic overprint acquired by the material cored with the demagnetized core barrel. This problem has arisen on previous ODP cruises (e.g., Legs 107 and 115). Its severity appears to vary considerably with the sediment type. On Leg 116, the problem was severe and resulted in few reliable magnetic inclination values being recorded.

Several other puzzling effects were noted in the remanent magnetization measurements. For example, a problem found in Hole $718 \mathrm{C}$ and $719 \mathrm{~A}$ sediments involved the distribution of declination values. In the former, the declination values were strongly peaked before AF demagnetization and in the latter the reverse was true (see Site Reports 718 and 719). As the biscuiting of sediments by XCB coring should result in a random declination distribution, these observations were unexpected. The results from Hole $718 \mathrm{C}$ suggested that the core acquired an overprint with a strong component in the horizontal plane. On the other hand, the results from Hole 719A suggested that the core acquired an overprint during measurement, possibly a anhysteretic remanent magnetization (ARM) caused by the in-line AF demagnetization coils within the cryogenic magnetometer.

Although the cryogenic magnetometer can also measure discrete samples and the shipboard magnetic laboratory is equipped with a spinner magnetometer and AF as well as thermal demagnetization equipment, only a few discrete samples were measured on board. Initial measurements indicated that the sediments recovered on Leg 116 were susceptible to the acquisition of viscous magnetizations. Moreover, some of the few samples demagnetized on board appeared to acquire an ARM in the AF demagnetizer. Consequently, discrete sample experiments were deferred for shore-based work in a magnetically cleaner environment.

Discrete samples were, however, obtained from most cores containing undisturbed sediments. In soft material, oriented samples were taken by pressing plastic boxes, with an internal volume of $7 \mathrm{~cm}^{3}$, into the split face of the core with one of the sides parallel to the upcore direction. To minimize the deformation due to sampling, a spatula was used to cut a thin trench on four sides of each sample to allow the easy insertion of the plastic box. Although this was done with care the method sometimes proved unsatisfactory for sampling softer sediments, as the plastic box tended to deform the sample. Other workers (Heath et al., 1985) have used specially made sharpened sample cutters with success on such sediments; consequently, much of 
the paleomagnetic sampling was deferred until a similar sample cutter could be built on shore. In some semi-indurated sediments, an oriented cube approximately $2 \mathrm{~cm}$ on a side was cut from a piece of the core using a spatula or a double-blade diamond saw. Some samples of more lithified units were taken by drilling minicores, $2.5 \mathrm{~cm}$ in diameter and $2.5 \mathrm{~cm}$ in length, perpendicular to the split-face of the core. These were inscribed with an arrow pointing in the up-core direction to provide orientation.

\section{GEOCHEMISTRY}

\section{Carbonate and Organic Carbon Determinations}

Shipboard organic carbon determinations were performed using a Coulometrics 5030 carbonate carbon apparatus to measure total carbon on ground and homogenized $20 \mathrm{~cm}^{3}$ samples. Approximately $40-50 \mathrm{mg}$ of these samples was weighed with a Cahn 29 Automatic Electrobalance, which averages a total of 50 weight measurements to compensate for ship heave. Combusted at $1000^{\circ} \mathrm{C}$ in an oxygen atmosphere, concentrations of evolving $\mathrm{CO}_{2}$ were determined against known standards and reported by the attached data station after background and blank corrections. Drift in the nitrogen detecting system and high blank values precluded the use of nitrogen concentrations and $\mathrm{C} / \mathrm{N}$ ratios for maturity and source determinations in most samples. Only safe and reliable values are reported in the tables. Carbonate carbon concentrations obtained from determinations with the Coulometrics Carbon Dioxide Coulometer Model 5010 were subtracted from total carbon to yield organic carbon. In the Coulometer, which has several distinct advantages over the carbonate bomb, $10-20 \mathrm{mg}$ of the sample are digested in $2 \mathrm{~mL} 2 \mathrm{~N}$ $\mathrm{HCl}$. The gas is carried into a coulometric cell where it reacts with ethanolamine and causes the indicator to fade. The change in absorbtion is monitored by a photocell (a base is created electrically by the titration circuit until the solution returns to its original color). Frequent blank and standard runs show that this method for carbonate-carbon determination has a relative error of less than $1 \%$, giving reliable values for subtraction of carbonate-carbon from total carbon to compute organic carbon. Standard runs and replicate analyses of standards of variable composition and $\mathrm{C}_{\text {org }}$ range show that this method has a relative error of less than $5 \%$ in sediments with $C_{\text {org }}$ concentrations above $0.3 \%$, and approximately $10 \%$ in organic carbon-lean sediments of less than $0.3 \% \mathrm{C}_{\text {org }}$.

\section{Gas Analyses}

Hydrocarbon gases, $\mathrm{C}_{1}$ through $\mathrm{C}_{5}$, were monitored on a Hewlett-Packard (HP) 5890A Gas Chromatograph (GC) using a flame ionization detector. Methane levels were generally low, thus allowing good separation between methane and gases of higher molecular weight on a DC200 packed column. Run time for the analysis was $9 \mathrm{~min}$. Methane, ethane, propane, $i$-butane, $n$-butane, $i$-pentane, and $n$-pentane separated in order of increasing retention time. Peak areas were measured and calibrated on a HP3392A Integrator and an HP3350 Laboratory Automation System (LAS).

Samples were collected through the core liner in vacutainers, and two $5-\mathrm{cm}^{3}$ sediment samples, used for headspace analysis, were collected upon initial sectioning of the core. One of the sediment samples was placed in a $20-\mathrm{cm}^{3}$ glass vial and sealed immediately with a septum and crimped metal cap. $5-\mathrm{cm}^{3}$ of He-degased surface seawater were added to the other sediment sample, which was sealed immediately, well-shaken, and treated like the other sample. This procedure has been tested at sea by Blanc et al. (1986). The vial was then heated in a hot oil bath at $70^{\circ} \mathrm{C}$ for $1 \mathrm{hr}$. The oil bath was part of the HP19395A Headspace Sampler (HSS). After equilibration, the HSS performs a preprogrammed sequence using an automated valve and loop sampling system. A sampling needle pierces the septum, and helium pressurizes the headspace vial. The headspace gas is vented to the GC through a $0.25-\mathrm{mL}$ sample loop. The loop is then flushed into the helium carrier gas flow, and the sample is delivered through a heated transfer line directly into the GC's injection port.

Vacutainer samples were delivered to the GC through the HSS. A 5-mL syringed sample was injected into a manual injection port on the HSS which filled the $0.25-\mathrm{mL}$ sample loop. The HSS then injected the sample to the GC as previously described.

Concentrations of hydrocarbon gases were computed from detector responses of canned gas standards, and preprogrammed methods were set up in the LAS to cover a wide range of concentrations.

\section{Interstitial Waters}

Interstitial waters were routinely analyzed for $\mathrm{pH}$, alkalinity, salinity, chlorinity, calcium, and magnesium during Leg 116. The method of obtaining interstitial waters from the sediment, using a stainless steel press, has been described in detail by Manheim and Sayles (1974). International Association of Physical Science Organizations (IAPSO) standard seawater is the primary standard for water analyses on board ship.

Alkalinity and $\mathrm{pH}$ were determined using a Metrohm titrator with a Brinkmann combination $\mathrm{pH}$ electrode. The $\mathrm{pH}$ value of the sample was calibrated with $4.01,6.86$, and 7.41 buffer standards; readings were taken in millivolts and then converted to $\mathrm{pH}$. The $\mathrm{pH}$ measurements were made immediately prior to the alkalinity measurements. The 1 - to 5 -mL interstitial water sample, after being tested for $\mathrm{pH}$, was titrated with $0.1 \mathrm{~N} \mathrm{HCl}$ as a potentiometric titration.

Salinity was determined using a Goldberg optical refractometer, which measures the total dissolved solids.

Chlorinity was determined by silver nitrate titration of a 0.1 $\mathrm{mL}$ sample diluted with $5 \mathrm{~mL}$ of deionized water. The Mohr titration uses potassium chromate as an indicator.

Calcium was determined by complexometric titration of a 0.5 -mL sample with ethylene-bis-(oxyethylene-nitrib)-tetra-acetic acid (EGTA) using 2, $2^{1}$-ethane-diyl-idine-dinitrilo-diphenol (GHA) as an indicator. To enhance the determination of the end point, the calcium-GHA complex was extracted into a layer of butanol. No correction was made for strontium, which is also included in the result.

Magnesium is determined by ethylene diomine tetra-acetic acid (EDTA) titration for total alkaline earths. Subsequent subtraction of the calcium value (also includes strontium) yields the magnesium concentration in the interstitial water sample.

For determination of $\mathrm{SO}_{4}{ }^{2-}$ by ion chromatography a $0.2 / 100$ dilution of the samples was prepared with deionized water. The samples were analyzed on the Dionex Ion Chromatograph, which is equipped with both anion and cation separation columns. The samples are compared to a series of standards containing concentrations of species varying from 0 to $61.4 \mathrm{mmol} / \mathrm{L}$ $\left(\mathrm{SO}_{4}{ }^{2-}\right)$ by a curve-fitting routine on the HP-97 calculator. Samples and standards are run in triplicate, and a water blank is run after each set of three to decrease the carry-over from set to set.

Silica was determined by production of Silicomolybdate complex on a $0.1 \mathrm{~cm}^{3}$ sample and reduction of this complex to give a blue color. Absorbtion at 812 nanometers was measured after $3 \mathrm{hr}$. Ammonia was determined by the phenol hydrochlorite method followed by absorption measurements at 640 nanometers. Phosphate was determined by reaction with a reagent containing molibdic acid, ascorbic acid and trivalent antimony. The resulting complex was reduced to give a blue solution. The absorption was measured at 885 nanometers. 


\section{PHYSICAL PROPERTIES PROCEDURES}

A thorough discussion of physical properties is presented by Boyce $(1973,1976)$ with respect to equipment, methods, errors, correction factors, and problems related to coring disturbance. Only a brief review of methods employed on Leg 116 is given here.

\section{GRAPE}

The Gamma-Ray Attenuation Porosity Evaluator (GRAPE), described in detail by Boyce (1976), was used to continuously measure the wet-bulk density of material in core sections over $50 \mathrm{~cm}$ long.

\section{Thermal Conductivity}

Thermal-conductivity measurements were made on sediments from cores which recovered material soft enough to yield to needle-probe insertion, down to about $450 \mathrm{mbsf}$. Data were collected by inserting needle probes through small (about $1-\mathrm{mm}$ diameter) holes drilled in the core liners. These probes are connected to a Thermcon-85 unit (Koehler and von Herzen, 1986) mated to a PRO-350 computer system. The software computes the coefficient of conductivity as a function of changes in resistance in the needles induced by changes in temperature over a 6min interval. One probe is inserted in a rubber standard and run with each set of measurements. Drift must be less than $4 \times 10^{-2}{ }^{\circ} \mathrm{C} / \mathrm{min}$ for reliable data. This accuracy requires allowing cores to thermally equilibrate to room temperature for at least $4 \mathrm{hr}$ prior to determining conductivity. The temperature drift was generally found to be less than this critical value at the time of thermal conductivity measurement.

\section{Vane Shear}

A complete discussion of the vane-shear apparatus and shearstrength measurement appears in Boyce (1973). Undrained shear strength was measured by a motorized vane shear rotating at $89^{\circ} \%$ $\mathrm{min}$. Measurements of vane-shear strength were routinely made on sediments with shear strengths less than about $400 \mathrm{kPa}$ (i.e., until the sediment was of sufficient cohesive strength to form drilling biscuits). Measurements were made perpendicular to the split core face for each interval sampled.

\section{Velocity}

Compressional wave velocity at $500 \mathrm{kHz}$ was measured through sediments and sedimentary rocks, with a Hamilton Frame Velocimeter using a Tektronix 5110 oscilloscope and Tektronix TM5006 Counter/Timer. Compressional wave velocity correction factors were calculated for each hole on Leg 116 as described in Boyce (1976).

\section{Index Properties}

Index properties (wet-bulk density, grain density, water content, and porosity) were routinely measured gravimetrically on the same samples for which compressional wave velocity was measured. Samples were placed in pre-weighed and numbered aluminum beakers and weighed in the beakers on a Kalm $29 \mathrm{Au}-$ tomatic Electrobalance that averages 50 weight measurements to compensate for ship heave. The volume of sample and container was then measured on the shipboard Penta-Pycnometer, which first purges the sample chamber of air, and then floods the sample chambers with helium gas at a pressure of $1.34 \mathrm{~kg} /$ $\mathrm{cm}^{2}$. The volume of sample and container is calculated from the difference between volume of helium in the empty sample chamber and in the chamber with sample. Samples were dried at $110^{\circ} \mathrm{C}$ for $24 \mathrm{hr}$, weighed, and their dry volume measured. Index properties were calculated by means of a computer program in which sample container and volume had been previously entered.
The pycnometer and electric balance used on board to compute grain density, wet-bulk density, and porosity have a precision of $\pm 0.05 \mathrm{~cm}^{3}$ and $\pm 0.02 \mathrm{~g}$. As a consequence, the measurements performed on board allowed a precision of grain density, wet-bulk density, and porosity of about $1 \%$ for unconsolidated sediments and about $2 \%$ for consolidated sediments and hard rocks.

Salinity-corrected physical properties were computed for all split-core samples assuming a pore-water salinity of $35 \%$.

After measurement of sample dry weight and dry volume, the carbonate content of the samples was measured using the $\mathrm{CO}_{2}$ Coulometer method.

\section{DOWNHOLE MEASUREMENTS}

\section{Logs}

Eight logging probes were available for use during Leg 116 (Table 1). The tools were developed by Schlumberger for oilfield applications, and in some cases were modified for use aboard the ship by ODP. Three or four tools are combined into a single string (Fig. 10) and these strings are lowered in three logging runs.

\section{Electrical Resistivity (DIL)}

The dual induction log provides three different measurements of electrical resistivity, each one with a different depth of investigation. Two induction devices (deep and medium resistivity) employ an array of coils operating at $25 \mathrm{kHz}$. The high-frequency alternating currents sent through the transmitter coils create magnetic fields which induce secondary (Foucault) currents in the formation (Fig. 11). These ground-loop currents produce new inductive signals, proportional to the conductivity of the formation, which are recorded by the receiving coils. The depth of penetration of the measurements is influenced by the spacing between transmitting and receiving coils. A third device (spherically focused resistivity) measures the current necessary to maintain a constant voltage drop across a fixed interval, at near-DC frequencies. The medium and deep resistivity devices provide a vertical resolution of around $2 \mathrm{~m}$, the focused resistivity of about $1 \mathrm{~m}$.

Water content and salinity are by far the most important factors controlling the electrical resistivity of rocks. To first order, the resistivity responds to the inverse square root of porosity (Archie, 1942). Other factors influence resistivity, such as the concentration of hydrous and metallic minerals, vesicularity, and geometry of interconnected pore space.

Table 1. Summary of log measurements.

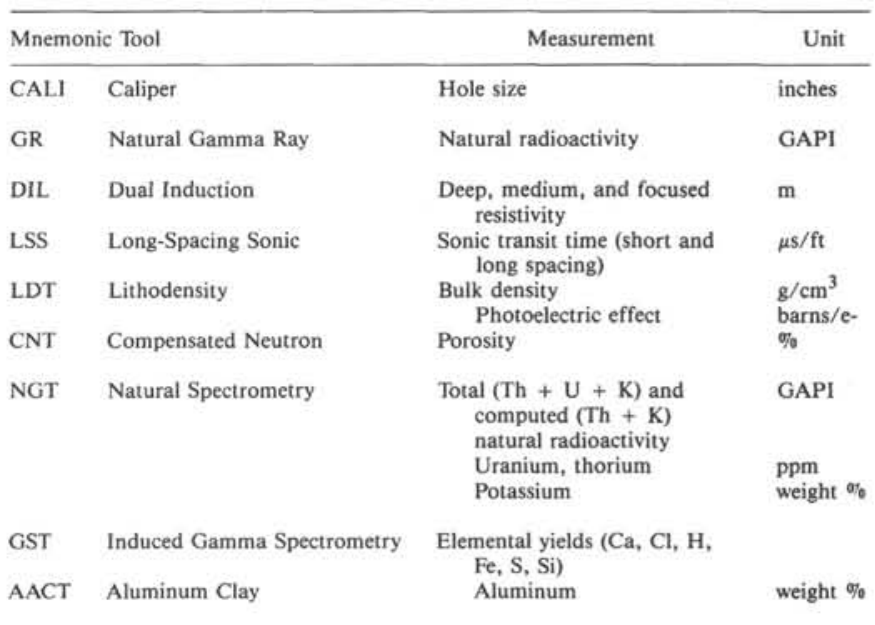




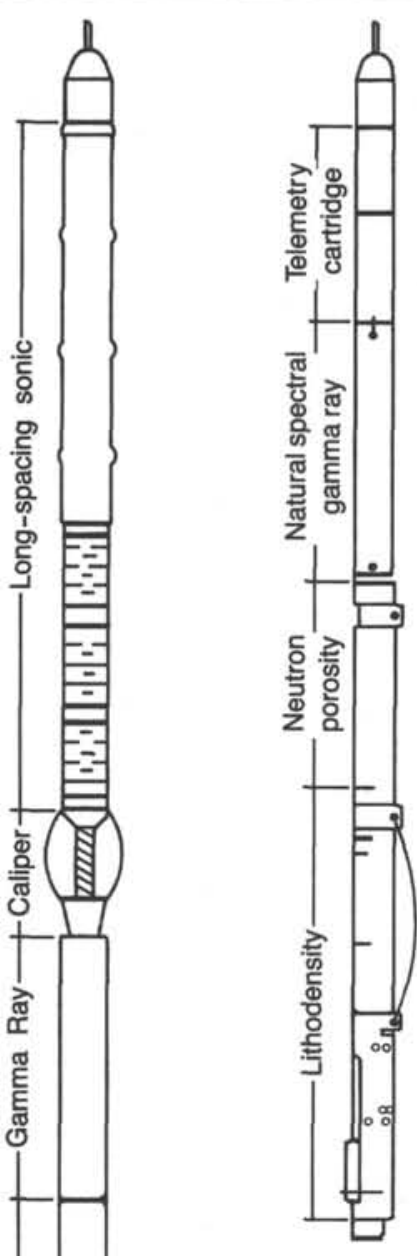

RUN 2

LDT-CNT-NGT

Length $12.1 \mathrm{~m}$

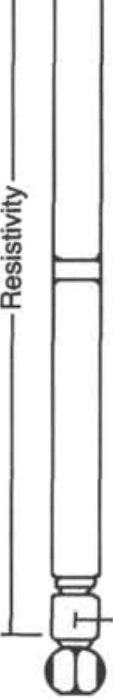

RUN 1

DIL-LSS-GR-CALI

Length $20.2 \mathrm{~m}$

Figure 10. Schematic diagram showing the combinations of logging tools run during Leg 116.

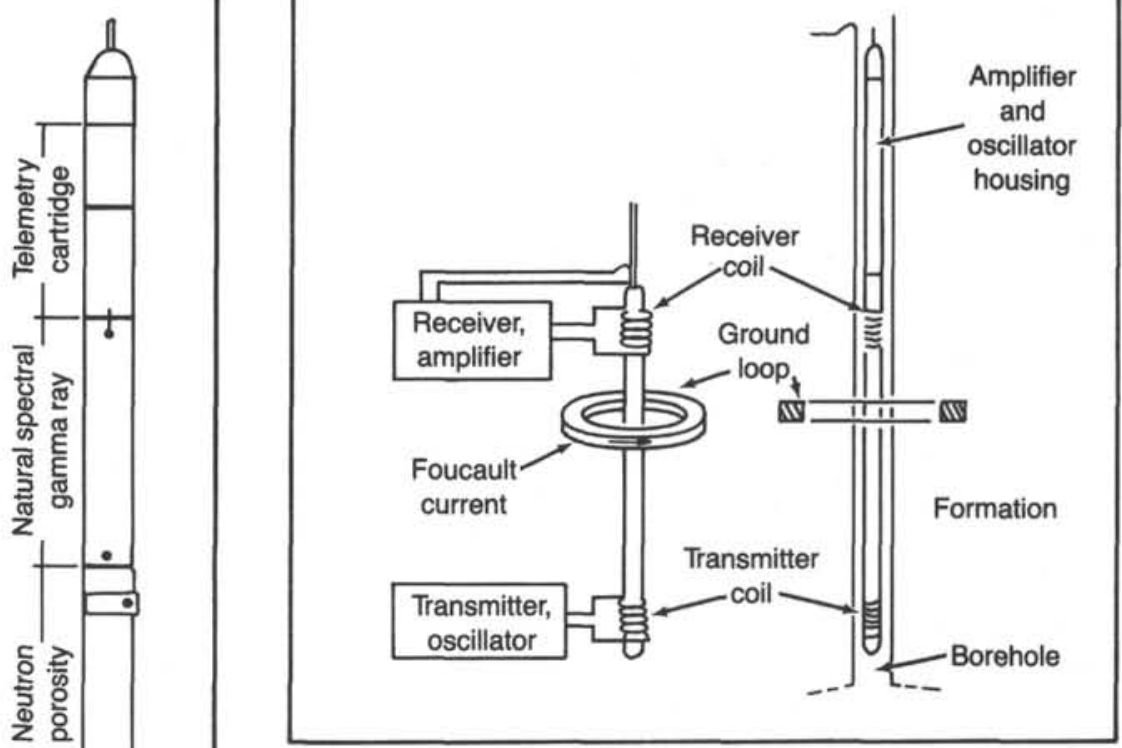

Figure 11. Basic two-coil induction log system (DIL) from Schlumberger (1972).

\section{Sonic Velocity (LSS)}

The long-spacing sonic probe uses two acoustic transmitters spaced $2 \mathrm{ft}(0.61 \mathrm{~m})$ apart and two receivers also spaced $2 \mathrm{ft}$ apart and located $8 \mathrm{ft}(2.43 \mathrm{~m})$ below the transmitters to measure the time required for a sound wave to travel through $1 \mathrm{ft}$ $(0.31 \mathrm{~m})$ of formation (Fig. 12). Compensation for borehole irregularities and inclination of the tool to the hole axis is obtained by memorizing the first transit time reading and averaging it with a second reading obtained after the sonde has been pulled up by a fixed distance along the borehole. First arrivals for the individual source-receiver paths are used to calculate the velocities of the different waves travelling in the formation (compressional, shear, etc.). The vertical resolution of the tool is about $0.61 \mathrm{~m}$. Compressional-wave velocity is dominantly controlled by porosity and lithification; decreases in porosity and increases in lithification cause the velocity to increase.

\section{Caliper (CALI)}

A three-arm caliper measures the borehole size as a function of depth. Such a measurement is often required to correct logs whose response is affected by the borehole diameter.

\section{Natural Gamma Ray (GR)}

The gamma-ray tool measures the natural radioactivity of the formation. Most gamma rays are emitted by the radioactive isotope of ${ }^{40} \mathrm{~K}$ and by the radioactive elements of the $\mathrm{U}$ and $\mathrm{Th}$ series. Passing through the material, gamma rays are scattered through collisions with the atoms of the formation, losing energy until they are absorbed. The gamma-ray radiation originating in the formation close to the borehole wall is measured by a scintillation detector mounted inside the sonde. The average formation depth of investigation is about $0.31 \mathrm{~m}$.

Because radioactive minerals tend to concentrate in clays and shales, the gamma-ray curve is often used to estimate the clay or shale content. There are rock matrices, however, whose radioactivity ranges from moderate to very high values, because of the presence of volcanic ash, potassic feldspar, or other radioactive minerals. 


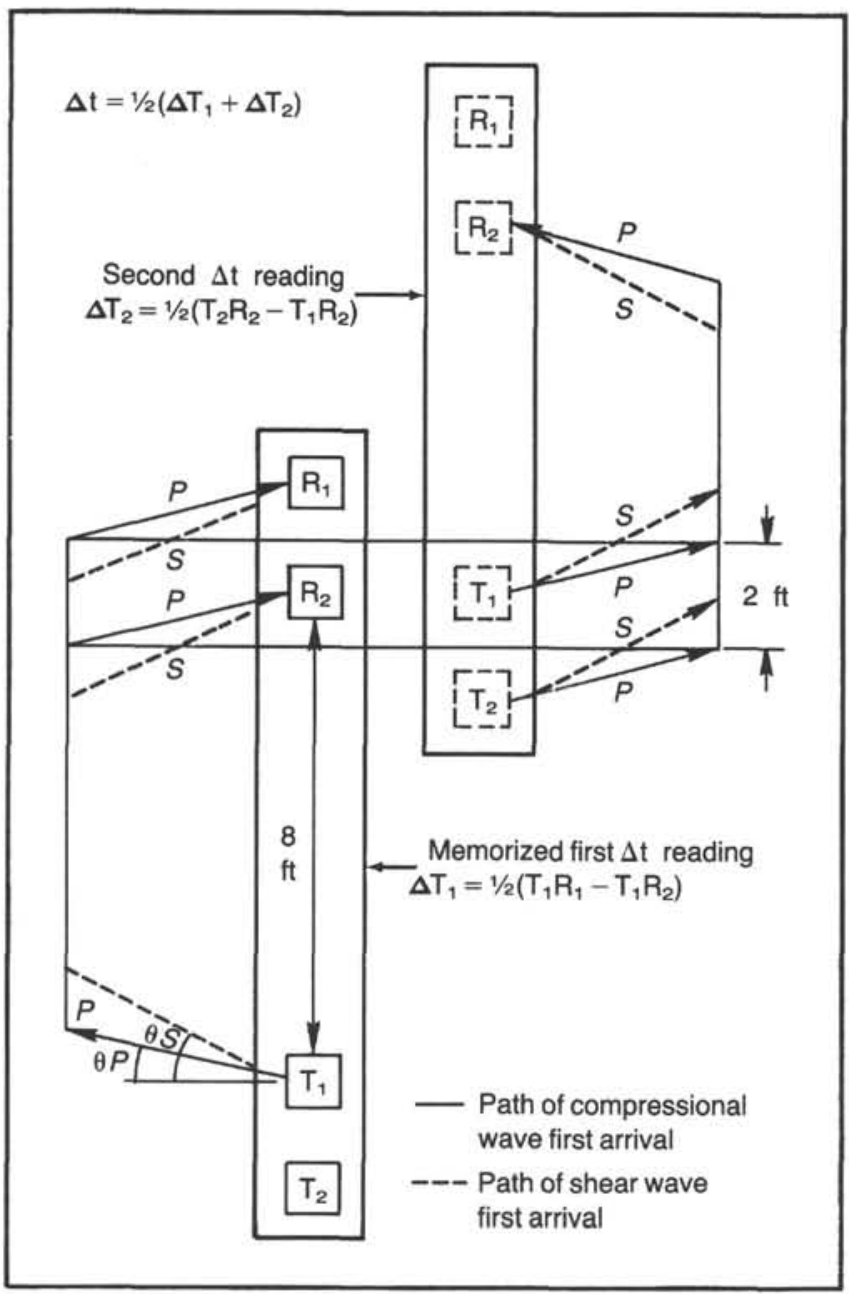

Figure 12. Long-Spacing Sonic (LSS) configuration. The first transit time reading $\left(T_{1}\right)$ is memorized and then averaged with a second reading $\left(\mathrm{T}_{2}\right)$ obtained after the sonde has been pulled up a fixed distance along the borehole (after Schlumberger, 1982).

\section{Lithodensity Tool (LDT)}

This tool utilizes a ${ }^{137} \mathrm{Ce}$ gamma-ray source to measure the resulting flux at fixed distances from the source. Under the operating conditions, attenuation of gamma rays is chiefly due to Compton scattering (Dewen, 1983); thus the resultant count rates can be related to the formation bulk density. The radioactive source and detector array is placed in a skid which is pressed against the borehole wall by a strong spring (Fig. 13). Excessive roughness of the hole will cause some drilling fluid to infiltrate between the skid and the formation. As a consequence, density readings will be artificially low. Corrections can be applied by using caliper data.

In addition to bulk density, a photoelectric effect index is also provided. Photoelectric absorption occurs in the energy window below $150 \mathrm{keV}$ and depends on the energy of the incident gamma ray, the atomic cross section, and the nature of the atom. Because this measurement is almost independent of porosity, it can be used directly as a matrix lithology indicator.

The depth of investigation by the lithodensity tool depends on the density of the rock-the greater the density, the less the penetration. In porous and permeable formations the density tool does not read deeper than $0.15 \mathrm{~m}$ into the formation. The vertical resolution is about $0.30 \mathrm{~m}$.

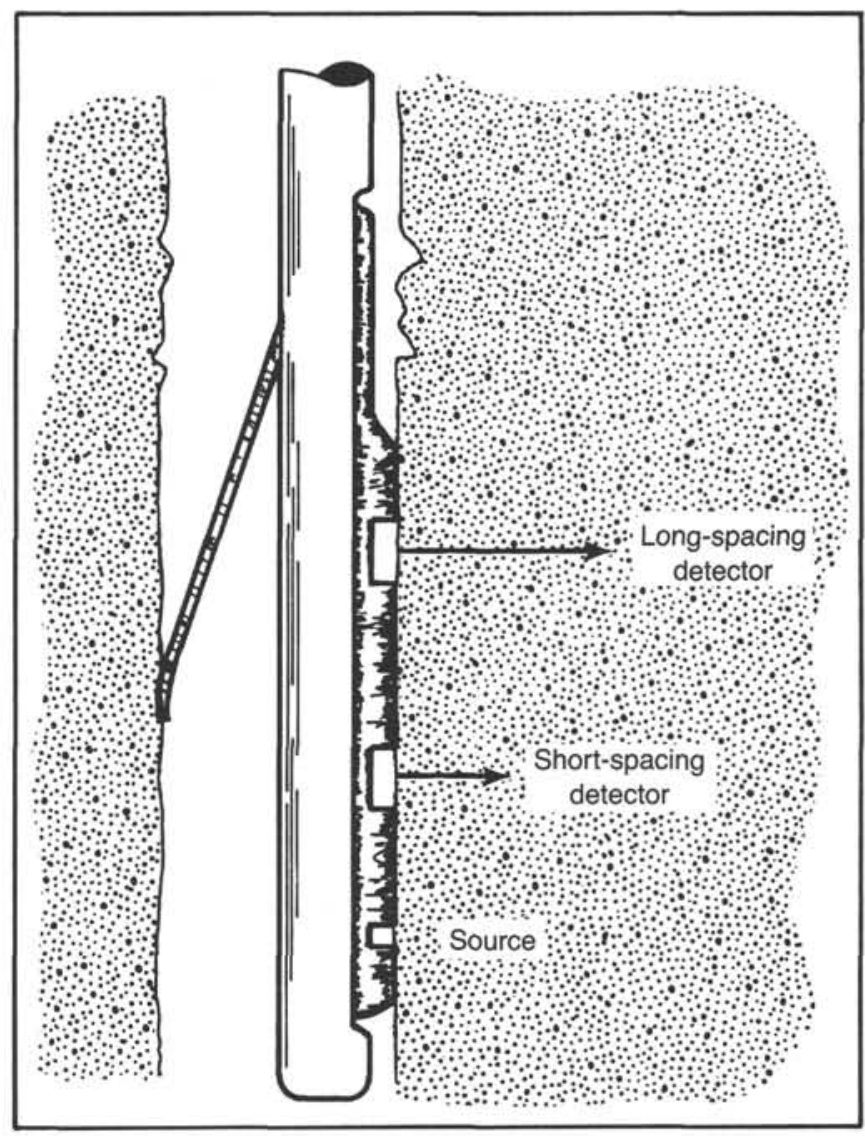

Figure 13. Dual-spacing lithodensity tool (LDT) after Schlumberger (1972). Good-quality readings are obtained when the detector skid is held in contact with the formation by a spring. Excessive roughness of the hole (upper part of the figure) will cause some drilling fluid to infiltrate between the skid and the formation and the readings will be artificially low.

\section{Compensated Neutron Porosity (CNT)}

A radioactive source mounted on the sonde emits fast neutrons $(5 \mathrm{MeV})$ into the formation, where they are scattered and slowed by collisions with other nuclei. When the neutrons reach a low energy level $(0.025 \mathrm{MeV})$ they are captured and absorbed by atomic nuclei such as hydrogen, chlorine, silicon, and boron. The scattering cross section is the quantity that describes the rate at which neutrons are slowed. Since the scattering cross section for hydrogen is about 100 times larger than for any other common element in the crust, most energy dissipation is caused by collisions with water molecules. Therefore, a change in the number of neutrons detected at a receiver can be related inversely to porosity. In practice, an array of detectors is used to minimize borehole or drilling-fluid effects. As with the LDT, the tool should be held in contact with the formation. Porosity measurements made in the presence of hydrous minerals will be overestimates of the true porosity. The vertical resolution of the tool is about $0.25 \mathrm{~m}$.

\section{Natural Spectral Gamma Ray (NGT)}

This tool measures the three different components $(\mathrm{K}, \mathrm{Th}$, and $U$ ) of the spectrum of the detected gamma rays, differentiating between gamma rays of different energies. The sonde consists of a sodium iodide detector contained in a pressure housing; a downhole electronic amplifier transmits pulses through the logging cable to the surface panels including a multichannel 
analyzer that displays the entire spectrum and selects pulses within preselected energy windows. The abundances of the individual radioactive elements are often distinctive markers.

The investigation depth of the tool depends on hole size, mud and formation density, and on the energy of gamma rays. Higher energy radiation can reach the detector from deeper in the formation.

\section{Induced Spectral Gamma Ray (GST)}

The tool consists of a pulsed source of $14-\mathrm{MeV}$ neutrons and a gamma-ray scintillation detector. A surface computer performs spectral analysis of gamma rays resulting from the interactions of neutrons emitted by the source with atomic nuclei in the formation. Several elements can be characterized by typical sets of gamma rays emitted through given neutron interactions. At each depth the computer determines a weighed least-squares estimate of the combination of standard spectra that best fits the logged gamma-ray spectrum (Hertzog, 1979).

Six elemental yields, (i.e., the contribution to the total spectrum), are calculated: $\mathrm{Ca}, \mathrm{Si}, \mathrm{Fe}, \mathrm{Cl}, \mathrm{H}$, and $\mathrm{S}$. As their sum is always one, they do not reflect the actual elemental composition. Therefore, ratios of these yields must be used in the interpretation of lithology, porosity, and salinity of the formation fluid.

The GST can be run through the drill pipe and in cased holes, thus it can be used in holes which otherwise could not be logged due to bad hole conditions. The GST is run in combination with the natural gamma spectrometry and neutron porosity tools. It is not run along with the lithodensity tool because both tools are designed to be located at the bottom of the tool string.

\section{Aluminum Clay (AACT)}

This tool utilizes a combination of a standard NGT, a modified NGT, and a modified CNT with a low-energy neutron source (Californium 252) to activate Aluminum in the formation and measure its weight percent concentration. In combination with the GST, the AACT provides the elemental measurements necessary to arrive at a determination of total clay volume and a means of quantitative clay typing.

The estimates of K from the NGT, Fe and Si from the GST, and $\mathrm{Al}$ from the AACT are sufficient for differentiating the relative amounts of Chlorite, Illite, Smectite, and Kaolinite. This continuous differentiation can then be compared with XRD and XRF measurements from core samples to establish a continuous, quantitative profile of mineralogy for logged intervals.

A summary of logging tools and their specifications are shown in Tables 1 and 2. A detailed description of logging tool functioning and of their applications is provided in Dewen (1983), Hertzog (1979), Schlumberger (1972), Serra (1984), and Timur and Toksoz (1985).

\section{Log Data Quality}

Log data quality may be seriously degraded in excessively large sections of the borehole or by rapid changes in the hole diameter. Resistivity and velocity measurements are less sensitive to borehole effects, while the nuclear measurements (neutron porosity and natural and induced spectral gamma ray) are most seriously impaired, because of the large attenuation by the borehole fluid. Corrections can be applied to the original data to reduce the effects of these conditions and, generally, any departure from the conditions under which the tool was calibrated.

One of the most serious problems that affects all logging data is the depth mismatching between logs and cores caused by ship heave during the recording. Small errors in depth matching can impair the results in zones of rapidly varying lithology. To minimize such errors, a hydraulic heave compensator adjusts for rig motion in real-time. Unfortunately, $100 \%$ accuracy is not obtainable in zones where core recovery is low because of the inherent ambiguity of placing the recovered section within the interval cored.

\section{Heat Flow}

\section{Equipment and Measurement Techniques}

Downhole temperatures are obtained during coring operation using two different types of equipment. During Advanced Piston Coring (APC) penetration of the uppermost sedimentary series, the Von Herzen temperature probe is used. The thermistor is located in a short and strong needle, at the base of the core barrel. Since the sediments proved unsuitable for APC coring, this instrument was not used during Leg 116.

During extended core barrel (XCB) drilling, the Uyeda/Kinoshita temperature probe was used. In this procedure an entirely self-contained temperature recorder is inserted into a core barrel with a thermistor probe protruding about $30-50 \mathrm{~cm}$ through the center of the core catcher. After drilling to the depth where a temperature measurement was scheduled, the core barrel was lowered on the wire line to the bottom of the drill string. Once the core barrel was locked into the bottom-hole assembly, the drill string was lowered to the bottom of the hole. Lowering pushed the thermistor probe into the undrilled sediment in front of the bit, where it remained for approximately 15-20 min. A new double collett system was used on Leg 116 to decouple the probe assembly from the drill-pipe motion, so that an undisturbed reading can be obtained.

Resistance of the thermistor was measured every $0.5 \mathrm{~s}$ and put into integrated circuit memory at either 1-min or 2-min intervals. Up to 128 readings can be stored in the memory (which gives a 2-hr 8-min operating record at a sampling rate of 1 sample per minute). An ideal temperature run should be marked by a rapid decrease in temperature as the probe is lowered though the water, followed by a relatively constant temperature as it is held at the mudline prior to insertion. Insertion should be marked by an abrupt friction heating effect, slowly decreasing back to the equilibrium temperature as the probe cools. Retrieval of the probe gives the reverse of the temperature profile obtained on lowering it. The final equilibrium temperature is usually not obtained while the probe is in the sediment, but can be determined by extrapolation of the observed cooling curve, which is asymptotically approaching the true sediment temperature.

Calm seas and an alert and skilled drilling team and lab technicians were major assets in the collection of high-quality data.

\section{REFERENCES}

Archie, G. E., 1942. The electrical resistivity $\log$ as an aid in determining some reservoir characteristics. Pet. Technol., 5, No. 1.

Barron, J. A., 1985. Neogene planktonic diatom biostratigraphy. In Bolli, H. M., Saunders, J. B., and Perch-Nielsen K. (Eds.), Plankton stratigraphy: Cambridge, U.K. (Cambridge University Press), 763-809.

Blanc, G., Boulegue, J., Badant, D., and Stouff, P., 1986. Premiers resultats de la campagne oceanographique Hydrotherm du Marion Dufresne sur la fosse Atlantis II. C.R. Acad. Sci. Paris, 302: 175180.

Blow, W. H., 1969. Late middle Eocene to Recent planktonic foraminiferal biostratigraphy. Proc. Int. Conf., Planktonic Microfossils, 1st, Geneva, 1967, 1: 199-422.

Bolli, H. M., and Saunders, J. B., 1985. Oligocene to Holocene low latitude planktic foraminifera. In Bolli, H. M., Saunders, J. B. and Perch-Nielsen, K., Plankton Stratigraphy: Cambridge, U.K. (Cambridge University Press), 155-263.

Boyce, R. E., 1973. Appendix I. Physical property methods. In Edgar, N. T., Saunders, J. B., et al., Init. Repts. DSDP, 15: Washington (U.S. Govt. Printing Office), 1115-1128. 
1976. Appendix I. Definitions and laboratory techniques of compressional sound velocity parameters and wet-water content, wet-bulk density, and porosity parameters by gravimetric and gamma ray attenuation techniques. In Schlanger, S. O., Jackson, E. D., et al., Init. Repts. DSDP, 33: Washington (U. S. Govt. Printing Office), 931-958.

Burckle, L. H., 1972. Late Cenozoic planktonic diatom zones from the eastern equatorial Pacific. Nova Hedwigia Beihefte, 39: 217-246.

Dewen, J. T., 1983. Essentials of Modern Open Hole Log Interpretations: Tulsa (Penwell).

DSDP, 1983. Design and operation of the hydraulic piston corer. DSDP Tech. Rept. 12.

1984. Design and operation of an advanced hydraulic piston corer. DSDP Tech. Rept. 21.

Gealy, J. M., Winterer, E. L., and Moberly, R. M., Jr., 1971. Methods, conventions, and general observations. In Winterer, E. L., Riedel, W. R., et al., Init. Repts. DSDP, 7, Pt. 1: Washington (U.S. Govt. Printing Office), 9-26.

Heath, G. R., Rea, D. H., and Levi, S., 1985. Paleomagnetism and accumulation rates of sediments at Sites 576 and 578, Deep Sea Drilling Project Leg 86, western North Pacific. In Heath, G. R., Burkle, L. H., et al., Init. Repts. DSDP, 86: Washington (U. S. Govt. Printing Office), 459-502.

Hertzog, R., 1979. Laboratory and field evaluation of an inelastic-neutron- scattering and capture gamma ray spectroscopy tool. Soc. Pet. Eng. Pap. 7430.

Kaczmarska, I., 1985. The diatom flora of Miocene lacustrine diatomites from the Harper Basin, Oregon, U.S.A. Acta Paleobot. 25: 33-100.

Koehler, R., and Von Herzen, R., 1986. A miniature deep sea temperature data recorder: Design, construction and use. Woods Hole Oceanographic Institute Tech. Rept. 86-3.
Manheim, F. T., and Sayles, F. L., 1974. Composition and origin of interstitial waters of marine sediments based on deep sea drill cores. In Goldberg, E. D., (Ed.), The Sea, Vol. 5, Marine Chemistry: New York (Wiley) 527-568.

Matthews, D. J., 1939. Tables of Velocity of Sound in Pore Water and in Seawater: London (Admiralty, Hydrographic Dept.).

Ross, D. A., Neprochnov, Y. P., and Supko, P., 1978. Introduction and explanatory notes, Leg 42B, Deep Sea Drilling Project. In Ross, D. A., Neprochnov, Y. P., et al., Init. Repts. DSDP, 42, Pt. 2: Washington (U.S. Govt. Printing Office), 3-15.

Sanfilippo, A., Westberg-Smith, M. J., and Riedel, W. R., 1985. Cenozoic radiolaria. In Bolli, H. M, Saunders, J. B., and Perch-Nielsen, K. P., Plankton Stratigraphy: Cambridge, U.K. (Cambridge University Press), 631-712.

Schlumberger, 1972. Log Interpretation (Vol. 1, Principles). New York (Schlumberger Ltd).

Serra, O., 1984. Detailed description of logging tool functioning and applications. In Developments in Petroleum Science series, Fundamentals of Well Log Interpretation 1: Amsterdam (Elsevier).

Shepard, F. P., 1954. Nomenclature based on sand-silt-clay ratios. $J$. Sediment. Petrol., 24: 151-158.

Timur, A., and Toksoz, M. N., 1985. Fundamentals of well log interpretation. Ann. Rev. Earth Planet. Sci., 13: 315-344.

Wentworth, C. K., 1922. A scale of grade and class terms of clastic sediments. J. Geol., 30: 377-390.

Ms 116A-103 